\title{
Fenomena Jurnalisme TikTok di Media Baru
}

\author{
Jilan Dwina SP* \\ Fakultas Ilmu Komunikasi, Universitas Islam Bandung, Indonesia. \\ *jilan.dwina99@gmail.com
}

Abstract. The medua currently provides many alternative choices for the public to consume all types of news, one of which is news in online form. Many important sifts have occurred in the process of delivering messages through the media, especially in a very advanced era, supported by the development of technology ang the digital world, media entrepreneurs choose to switch to various platforms that can be profitable, not only by using their website but all over the world. Social media such as Twitter, Facebook, Instagram and TikTok are used by the media to keep reporting varios news that are happening. TkTok is one of the appliactions that is currently the most uploaded by the public. CNBC Indonesia, Urbanasia.com abd TribunJabar.id are media that participate in using TikTok in their news distribution media. This study aims to obtain data and also information related to the use and production process of news on TikTok as well as ethics and journalistic rules in news videos uploaded on TikTok which are one of the ain highlights. Data collection techniques used in, this research are interviews, observation and literature study. The editorial team from CNBC Indonesia, Urbanasia.com and TribunJabar.id media were informants and also rsource persons in this research. By using qualitative research methods with a case study approach, the researcher tries to uncover the phenomena of TikTok journalism in new media.

Keywords: Journalism, TikTok, New Media.

\begin{abstract}
Abstrak. Media saat ini memberikan banyak sekali pilihan alternatif kepada masyarakat untuk mengonsumsi semua jenis pemberitaan salah satunya pemberitaan dalam bentuk online. Banyak pergeseran penting yang terjadi dalam proses penyampaian pesan melalui media khususnya di era yang sangat maju seperti saat ini dengan di dukung perkembangan teknologi dan dunia digital para pangusaha media memilih untuk beralih ke berbagai platform yang dapat menguntungkan, tak hanya memanfaatkan laman website-nya tetapi seluruh media sosial seperti Twitter, Facebook, Instagram dan TikTok digunakan media-media untuk terus mengabarkan berbagai pemberitaan-pemberitaan yang terjadi. TikTok menjadi salah satu aplikasi yang saat ini paling banyak diunggah oleh masyarakat. CNBC Indonesia, Urbanasia.com dan TribunJabar.id merupakan media-media yang turut serta memanfaatkan TikTok dalam media penyebaran beritanya. Penelitian ini bertujuan untuk mendapatkan data dan juga infromasi terkait pemanfaatan serta proses produksi pemberitaan di TikTok dan juga etika dan kaidah jurnalistik dalam video pemberitaan yang diunggah di TikTok yang menjadi salah satu sorotan utama. Teknik pengumpulan data yang digunakan dalam penelitian ini yaitu wawancara, observasi dan studi pustaka. Tim redaksi dari media CNBC Indonesia, Urbanasia.com dan TribunJabar.id menjadi informan dan juga narasumber di dalam penelitian ini. Dengan menggunakan metode penelitian kualitatif dengan pendekatan studi kasus, peneliti berusaha menguak fenomena-fenomena jurnalisme TikTok di media baru.
\end{abstract}

Kata Kunci: Jurnalisme TikTok, Media Baru. 


\section{A. Pendahuluan}

Banyak pergeseran penting yang terjadi dalam proses penyampaian pesan melalui media. Selama ini media merupakan sumber utama informasi kemudian informasi tersebut dipublikasikan secara satu arah kini media sendiri menjadi jauh lebih interaktif. (Nasrullah, 2014:1). Hadirnya media baru merupakan suatu media yang memberikan cakupan yang lebih luas dan muncul akibat adanya inovasi teknologi dalam bidang media seperti $t v$ kabel, satelit, teknologi optic fiber, serta komputer (Croteau, 1997: 12).

Media yang saat ini banyak digunaan masyrakat yaitu media sosail, yang menjadikan alasan para pengguna media sosial menggunakan media sosial sebagai sumber informasi yaitu, adanya motif informasi seperti mencari berita mengenai peristiwa dan kondisi yang berhubungan dengan lingkungan sekitar, masyrakat dan dunia; mencari panduan dari berbagai masalah, pendapat dan hal-hal yang bersangkutan dengan penentuan pilihan; kemudian untuk memenuhi rasa ingin tahu dan minat umum; belaajr, pendidikan diri sendiri; serta memperoleh rasa damai mealui penambahan pengetahuan (McQuail, 1991:72)

Pemilik media saat inipun banyak yang memilih untuk membuka akun di media sosial. Tidak hanya memanfaatkan satu kanal berita online lewat websitenya, dapat diketahui media saat ini sudah hadir di berbagai platform media sosial.

Aplikasi media sosial yang digandrungi masyarakat hampir satu tahun terakhir ini adalah aplikasi yang berasal dari Tiongkok milik perusahaan ByteDance yaitu TikTok. Dikutip dari laman resmi SensorTower, dalam laporan Top Apps Worldwide for February 2021 by Downloads tercatat TikTok sebagai aplikasi non gaming yang paling banyak diunduh lebih dari 56 juta kali di bulan Februari 2021.

\section{Bagan 1.1 TikTok Global Download by Quarter}

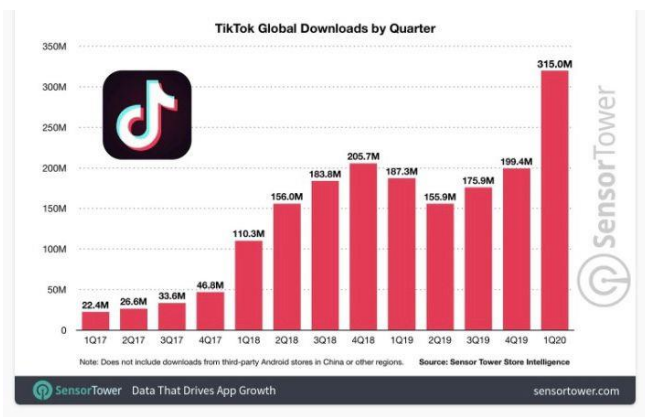

Sumber: sensortower.com

Selain itu bersumber dari Priori Data yang dikutip dari katadata.co.id menyatakan di Indonesia sendiri aplikasi TikTok sudah diunduh sebanyak 30,7 juta kali. Masyarakat Indonesia yang menggunakan TikTok rata-rata menghabiskan waktu selama 29 menit perhari dan menonton 100 video perharinya. 
Bagan 1.2 Negara dengan Jumlah Unduhan TikTok Terbanyak

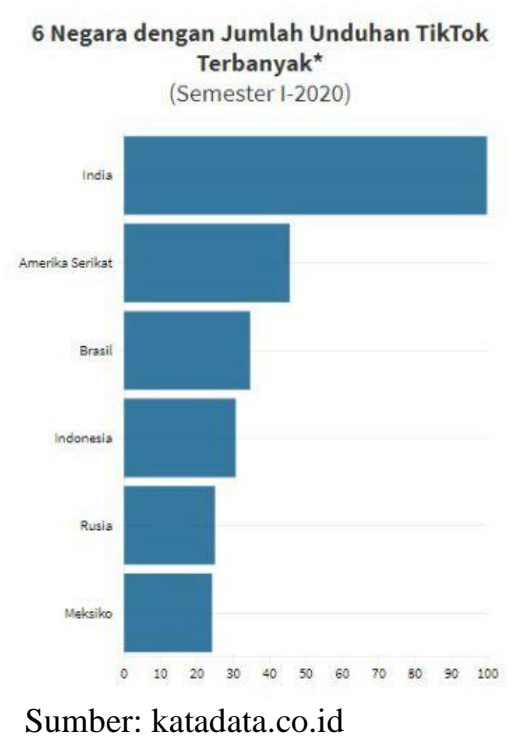

Baik media online maupun media konvensional saat ini masing-masing sudah memiliki akun TikTok-nya. Dalam akun TikTok-nya para media mengunggah pemberitaan dengan menampilkan video-video pemberitaan dengan gaya khas masing-masing media. Dimulai dari video berita darurat hingga video berita ringan mereka sajikan secara singkat di TikTok. Video pemberitaan yang diunggah oleh akun-akun media konvensional ini selain memiliki ciri khas masing-masing dalam unggahannya, mereka juga memanfaatkan caption informatif dan juga fitur hashtags yang bisa menyalurkan video tersebut ke berbagai segmentasi yang dituju.

Tiga media yang dipilih dalam penelitian ini memiliki ciri khas yang berbeda dalam video pemberitaannya. Video pemberitaan pertama dari akun TikTok CNBC Indonesia. CNBC Indonesia di TikTok memiliki followers 122,5 ribu, kebanyakan video yang diunggah merupakan potongan dari berita yang ditayangkan di televisi. Akun TikTok CNBC Indonesia juga memanfaatkan fitur hashtags dengan pemilihan hashtags yang memiliki kaitan dengan isi video. Video di TikTok CNBC Indonesia juga dapat langsung terhubung dengan artikel di website resmi milik CNBC Indonesia, yaitu www.cnbcindonesia.com.

Kemudian media online Urbanasia.com salah satu media online terbaru yang memiliki ciri khas unik dalam video pemberitaannya di TikTok. Dengan followers 2,7 juta di akun TikTok-nya, Urbanasia.com menyuguhkan berita dengan gaya TikTok yang kekinian. Yang sangat berbeda dari akun pemberitaan milik media lainnya, akun media Urbanasia.com menyuguhkan video pemberitaan dengan dibacakan langsung oleh sang presenter, dengan didukung backsound yang sesuai dengan jenis pemberitaan dan juga menambahkan teks informasi terkait berita di dalam video yang diunggah membuat video yang disajikan tidak begitu formal.

Terakhir surat kabar Tribun Jabar yang memiliki portal online TribunJabar.id juga memiliki akun resmi di TikTok. Dalam unggahannya di TikTok video pemberitaan secara singkat dan tanpa voice over mereka suguhkan Unggahan video dari TribunJabar.id juga menggunakan template frame khas warna Tribun yaitu biru muda. TribunJabar.id juga memanfaatkan fitur hashtags \#fyp pada beberapa unggahannya. TribunJabar.id memiliki followers sebanyak 74,3 ribu di TikTok.

Berdasarkan latar belakang yang telah diuraikan, maka perumusan masalah dalam penelitian ini sebagai berikut:"Bagaimana jurnalisme TikTok di media baru merepresentasikan etika dan kaidah jurnalistik dalam video pemberitaannya". Selanjutnya, tujuan dalam penelitian ini diuraikan dalam pokok-pokok sbb.

1. Untuk mendapatkan data dan informasi terkait pemanfaatan TikTok dari Media CNBC Indonesia, Urbanasia.com dan TribunJabar.id sebagai platform pemberitaan. 
2. Untuk mendapatkan data dan informasi terkait proses produksi video pemberitaan di TikTok dari Media CNBC Indonesia, Urbanasia.com dan TribunJabar.id.

3. Untuk mendapatkan data dan informasi terkait penerapan etika dan kaidah jurnalistik dalam jurnalisme TikTok.

\section{B. Metodologi Penelitian}

Penelitian ini menggunakan metode penelitian kualitatif dengan pendekatan studi kasus dan paradigma konstruktivisme. Peneliti memilih menggunakan metode penelitian kualitatif sesuai dengan dua tujuan penelitian kualitatif sendiri yaitu menggambarkan dan mengungkapkan juga menggambarkan dan menjelaskan.

Penelitian ini bermaksud untuk mengetahui lebih lanjut mengenai fenomena jurnalisme yang saat ini hadir di platform digital TikTok secara lebih rinci. Sesuai dengan tujuan dari penelitian kualitatif itu sendiri. Maka dari itu pendekatan studi kasus tunggal holistik juga dipilih sebagai pendeketan dalam penelitian ini dikarenakan, studi kasus tunggal cocok dengan penelitian ini yang memfokuskan pada satu kasus dan kasus bersifat unik. Kasus yang diteliti pun dapat menjadi gambaran dari kasus-kasus serupa lainnya.

Objek penelitian ini yaitu akun resmi TikTok milik ketiga media yang sudah di pilih sebagai berikut, CNBC Indonesia, Urbanasia.com dan TribunJabar.id. Subjek penelitian yang dipilih pun merupakan tim redaksi dari ketiga media tersebut. CNBC Indonesia dengan Sosial Media Reporter, Urbanasia.com dengan Pimpinan Redaksi \& Content Director, TribunJabar.id dengan Koordinator Video \& Admin TikTok TribunJabar.id.

Teknik pengumpulan data yang dilakukan dalam penelitian ini yaitu melalui wawancara mendalam yang dilakukan kepada pihak yang memiliki peranan penting dengan akun TikTok dari masing-masing media, lalu observasi dengan melakukan pengamatan secara sistematis terhadap ketiga akun TikTok milik media yang dipilih juga ketika wawancara berlangsung, kemudian yang terakhir studi pustaka yang bersumber dari buku, e-book, jurnal, penelitian terdahulu dan sumber bacaan lainnya untuk menambah informasi yang dapat membantu berjalannya penelitian ini.

Kemudian untuk teknik analisis data penulis memilih beberapa teknik analisis data yaitu, Analisis sebelum di lapangan dengan tujuan mendapatkan data lebih awal yang untuk penentuan fokus penelitian. Dengan melakukan observasi terlebih dahulu pada akun resmi TikTok milik media CNBC Indonesia, Urbanasia.com dan TribunJabar.id. Kemudian analisis menggunakan model Miles dan Huberman. Dengan pengumpulan data, reduksi data, data display serta memaparkan kesimpulan/verifikasi. Berikut bagan Teknik analisis data yang digunakan penulis berdasarkan Miles dan Huberman.

Bagan 2.1 Miles dan Huberman

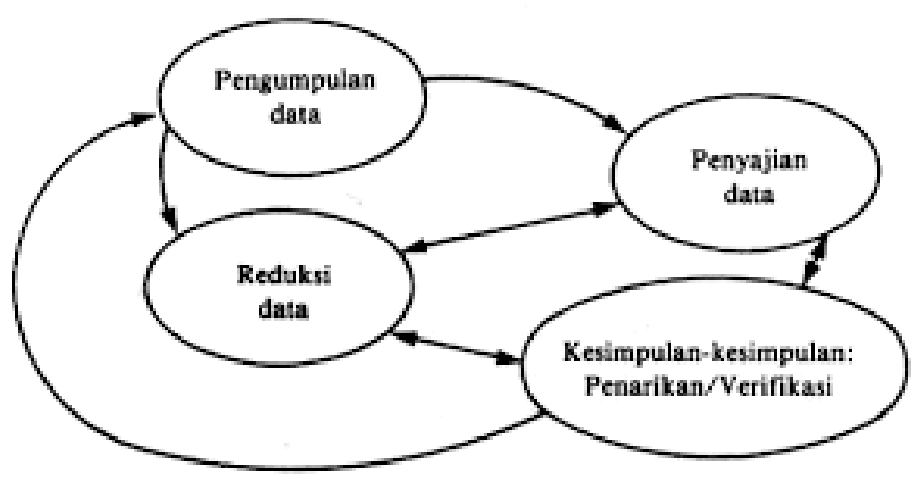

Tahap pengumupulan data sendiri sama seperti yang sudah dipaparkan sebelumnya. Kemudian memasuki reduksi data dalam proses yang dilalui peneliti memilah, menyederhanakan, memiisahkan dan memfokuskan data-data yang masih belum diolah dalam catatan lapangan dan proses input dilakukan selama penelitian berlangsung. 
Proses berikutnya data display atau penyajian data informasi yang telah berhasil disusun kemudian diperbolehkan untuk mengambil tindakan atau membuat kesimpulan dari informasi tersebut.

Terakhir membuat kesimpulan atau verifikasi kembali secara ringkas dan padat agar intisari dari pembahasan dapat dijelaskan dan mudah untuk dimengerti. Data yang berada dikesimpulan merupakan data yang diperoleh dari observasi, wawancara dan verifikasi oleh peneliti dalam penelitian ini.

\section{Hasil Penelitian dan Pembahasan}

\section{Pemanfaatan Platform TikTok Sebagai Platform Pemberitaan oleh CNBC Indonesia Urbanasia.com dan TribunJabar.id}

Contextualized journalism sebagai tipe baru dari jurnalisme online menurut (Santana, 2005:137) dalam memadukan ketiga fitur komunikasi yang unik, yaitu multimedia, interaktif dan hipertekstual. Multimedia sendiri sudah jelas dengan penggabungan sebuah teks, audio, grafis, gambar dan video ini menjadi keharusan di aplikasi TikTok. Lalu, interaktif disediakannya kolom komentar di setiap unggahan di TikTok membuat kemudahan dalam berinteraksi antara kreator dengan audience nya. Terakhir hipertekstual, ini digunakan untuk mempermudah pengguna TikTok dalam menacri informasi lebih banyaj lagi.

TikTok digunakan oleh ketiga media ini yang sudah memanfaatkan ketiga hal tersebut. Peneliti membuat perbandingan diantara ketiga media yang sudah memenuhi contextualized journalism sebagai bentuk baru dari jurnalisme online melalui tabel berikut ini.

Tabel 3.1 Perbandingan Contextualized Journalism di Ketiga Media

\begin{tabular}{|l|l|l|l|}
\hline $\begin{array}{c}\text { Contextualized } \\
\text { Journalism }\end{array}$ & \multicolumn{1}{|c|}{ CNBC Indonesia } & \multicolumn{1}{|c|}{ Urbanasia.com } & TribunJabar.id \\
\hline Multimedia & $\begin{array}{l}\text { Dalam akun CNBC } \\
\text { Indonesia, sudah terdapat } \\
\text { penggabungan teks, audio, } \\
\text { grafis dan video }\end{array}$ & $\begin{array}{l}\text { Dalam akun Urbanasia.com } \\
\text { pun, sudah ada } \\
\text { penggabungan antara teks, } \\
\text { audio, gambar dan video. }\end{array}$ & $\begin{array}{l}\text { Dalam akun } \\
\text { TribunJabar.id juga } \\
\text { terdapat } \\
\text { penggabungan teks, } \\
\text { audio, grafis dan } \\
\text { video. }\end{array}$ \\
\hline \multirow{5}{*}{ Interaktif } & $\begin{array}{l}\text { CNBC Indonesia } \\
\text { membalas setiap komentar } \\
\text { yang ada di unggahan } \\
\text { videonya, ini } \\
\text { menunjukkan bahwa } \\
\text { media CNBC Indonesia } \\
\text { interaktif dengan audience } \\
\text { nya. }\end{array}$ & $\begin{array}{l}\text { Urbanasia.com membuka } \\
\text { kolom komentamya di } \\
\text { setiap unggahan video nya, } \\
\text { mereka tidak membalas satu } \\
\text { persatu tetapi memberikan } \\
\text { like di beberapa komentar } \\
\text { yang diberikan untuk } \\
\text { menunjukkan ke interaktif- } \\
\text { an nya. }\end{array}$ & $\begin{array}{l}\text { TribunJabar.id pun } \\
\text { membuka kolom } \\
\text { komentar tetapi tidak } \\
\text { membalas satu } \\
\text { persaty dari setiap } \\
\text { komentar yag } \\
\text { diberikan. }\end{array}$ \\
\hline Hipertekstual \\
& $\begin{array}{l}\text { Penggunaan hipertekstual } \\
\text { CNBC Indonesia, yang } \\
\text { akan memudahkan } \\
\text { pengguna TikTok } \\
\text { menemukan profile } \\
\text { ataupun video yang } \\
\text { berkaitan dengan CNBC } \\
\text { Indonesia. }\end{array}$ & $\begin{array}{l}\text { Penggunaan hipertekstual } \\
\text { Urbanasia.com } \\
\text { memudahkan untuk } \\
\text { menemukan profile dan } \\
\text { video terbaru dari } \\
\text { Urbanasia.com. }\end{array}$ & $\begin{array}{l}\text { Penggunaan } \\
\text { hipertekstual } \\
\text { TribunJabar.id } \\
\text { memudahkan untuk } \\
\text { menemukan profile } \\
\text { dan video yang } \\
\text { memiliki viewers } \\
\text { terbanyak dari } \\
\text { TribunJabar.id }\end{array}$ \\
\hline
\end{tabular}

Sumber: Olahan Data Peneliti

Dari uraian tabel diatas dapat dilihat bahwa ketiga media dalam penelitian ini sejalan dengan teori yang diungkapkan Septiawan Santana terkait bentuk baru dari jurnalisme online ini.

CNBC Indonesia, Urbanasia.com dan TribunJabar.id memiliki alasan yang sama mengenai hadirnya mereka di platform TikTok yaitu branding, untuk memperluas market pembaca mereka di situs web nya. Sehingga eksistensi mereka dikenal oleh berbagai kalangan, khususnya kalangan anak muda yang menggandrungi TikTok menjadi targetnya saat ini.

Selain itu terkait dengan gaya pemberitaan yang unik dari setiap media ini memiliki latar belakang yang berbeda. CNBC Indonesia merasa bahwa identitas mereka sebagai media ekonomi, mereka tidak akan bisa menjelaskan dengan gaya pemberitaan yang formal di TikTok karena hal itu menurutnya akan sulit untuk di pahami oleh viewers. 
Sedangkan Urbanasia.com memiliki latar belakang keresahan akan para pengguna TikTok yang menyebarkan banyak berita hoax, banyak dari pengguna TikTok yang berkegiatan jurnalistik tetapi tidak menggunakan etika jurnalistik hal ini menyebabkan TikTok dapat dikatakan sebagai homeless media. Gaya pemberitaan yang mereka gunakan dengan cara diungkapkan langsung oleh host nya sama seperti influencer-influencer TikTok banyak menarik minat para pengguna TikTok. Hal ini pun menjadikan cara Urbanasia.com memanfaatkan platform ini untuk menyebarkan berita dengan kebenaran dan juga fakta yang terjamin kredibilitasnya.

Sedangkan TribunJabar.id memanfaatkan platform TikTok ini berdasarkan sesuatu yang tak disengaja, melihat respon bagus dari masyarakat TikTok, TribunJabar.id ingin memberikan sesuatu yang lebih, dengan menggarapnya lebih serius. Sehingga pemberitaan yang disampaikan tersebar lebih luas lagi. TribunJabar.id juga sebagai salah satu media yang mengutamakan konvergensi media dalam penelitian ini, dengan latar belakang sebagai koran cetak saat ini TribunJabar.id juga ikut berpindah ke digital dan berusaha untuk mengsinergiskan seluruh produk jurnalistiknya antara cetak dan digital.

Salah satunya yang dimanfaatkan oleh TribunJabar.id ini yaitu scan barcode yang tertera di koran cetaknya, scan barcode tersebut terkadang tersambung dengan pemberitaan yang ada di TikTok atau sosial media yang lain. Hal ini menjadikan pendistribusian konten bisa dilakukan di berbagai platform.

Meskipun dalam penjelasan konvergensi penyajian sejalan dengan yang dilakukan oleh CNBC Indonesia dan Urbanasai.com tetapi kedua media ini tidak mengutamakan hal tersebut, hal ini berdasarkan latar belakang kedua media tersebut yang memang lahir sebagai website. Langkah-langkah utama yang CNBC Indonesia lakukan dalam memanfaatkan TikTok ini cukup dengan melihat berita yang sedang ramai dibaca di website memiliki kecocokan tidak ketika diunggah kembali dengan gaya TikTok.

Lain halnya dengan Urbanasia.com yang juga tidak mengutamakan konvergensi media, media ini juga memanfaatkan nya bergantung dengan berita di website, beragam berita yang hadir di website sebisa mungkin akan diunggah juga di TikTok. Kerjasama antara Urbanasia.com dan TikTok menjadikan media ini memanfaatkan platform TikTok semaksimal mungkin terkhusus dalam proses menyampaikan berita kepada khalayak. Dengan begitu di ketiga media ini memiliki berbagai cara masing-masing dalam memanfaatkan platform TikTok sebagai platform pemberitaan.

\section{Proses Produksi Video Pemberitaan Media CNBC Indonesia, Urbanasia.com dan} TribunJabar.id di TikTok

Sudah menjadi tugas utama media massa dalam mengabarkan setiap peristiwa-peristiwa yang terjadi, beragam bentuk sebuah pemberitaan dapat disuguhkannya. Bergantung lewat platform mana yang akan digunakan untuk mendeliver setiap informasinya. Pemberitaan media CNBC Indonesia, Urbanasia.com dan TribunJabar.id di TikTok digambarkan dengan caranya masingmasing, setiap media memiliki ciri khas tersendiri dalam hal menyampaikan beritanya.

Proses pembentukan sebuah video pemberitaan di TikTok dari sebuah video mentah sampai menjadi output video yang dapat diunggah, dari masing-masing media akan peneliti paparkan sebagai berikut; Berita yang diunggah dari website CNBC Indonesia, kemudian diunggah kembali di setiap sosial media, seperti Facebook dan Twiter.

Sedangkan beberapa berita pilihan diunggah di Instagram. Kemudian berita yang akan diunggah di TikTok merupakan berita yang dikurasi oleh reporter sosial media.

Reporter sosial media membuat konsep yang kemudian diserahkan kepada tim editor/motion untuk diolah, setelah itu dipreview oleh pimpinan redaksi yang kemudianakan diunggah di TikTok dan disebarkan lah link kepada pihak TikTok untuk ikut membantu up pembertiaan CNBC Indonesia.

Untuk setiap video pemberitaan akan melewati proses yang sama, maka dari itu CNBC Indonesia memilih dalam satu minggu hanya ada satu sampai dua video saja yang mampu naik di TikTok dikarenakan panjangnya proses setiap video untuk tayang d TikTok. 
Bagan 3.1 Proses Pemberitaan CNBC Indonesia di TikTok

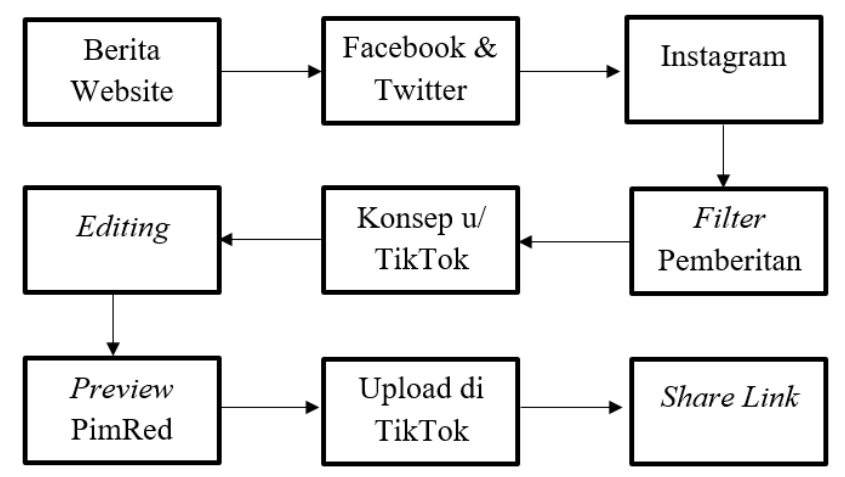

Sumber: Olahan Data Peneliti

Kemudian proses pembentukan sebuah video pemberitaan TikTok Urbanasia.com sebagai berikut;

Bagan 3.2 Proses Pemberitaan Urbanasia.com di TikTok

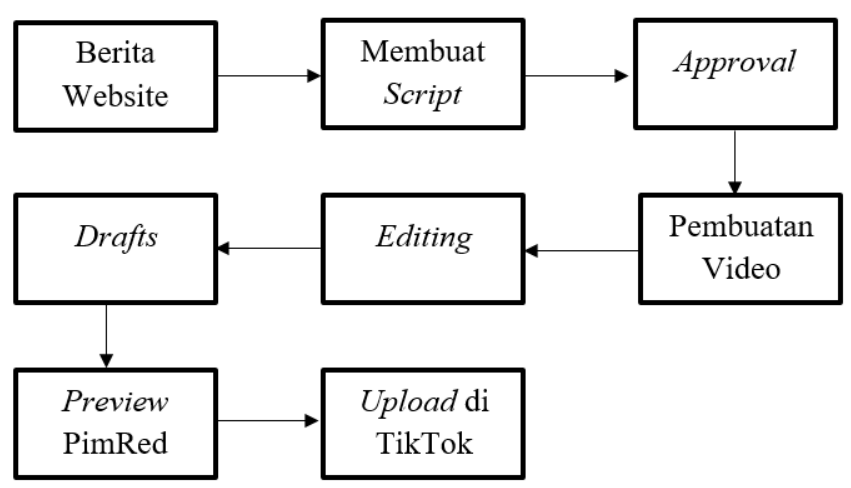

Sumber: Olahan Data Peneliti

Dalam proses ini, berita yang berasal dari website kemudian akan dibuat script yang membutuhkan approval dari pimpinan redaksi sebelum ke proses pembuatan video, kemudian untuk editing dilakukan langsung oleh tim sosial media Urbanasia.com dimana yang masih hanya memiliki satu orang di dalam tim nya.

Setelah video selesai di buat dan di proses, sebelum di upload tim sosial media akan menyimpannya di drafts TikTok untuk di preview terlebih dahulu oleh pimpinan redaksi yang menjadi narasumber dalam penelitian ini, setelah mendapatkan approval video tersebut baru dapat diunggah di akun Urbanasia.com

Selanjutnya, TribunJabar.id juga memiliki proses pembentukan berita di TikTok namun berbeda dengan dua media sebelumnya, yaitu sebagai berikut:

Bagan 3.3 Proses Pemberitaan TribunJabar.id di TikTok

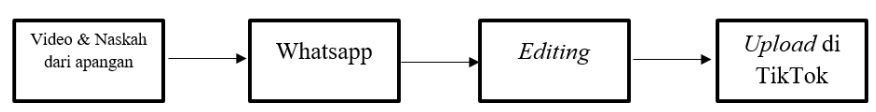

Sumber: Olahan Data Peneliti 
Proses yang dijalankan oleh TribunJabar.id terbilang lebih singkat dari kedua media sebelumnya maka dari itu Tribun memiliki target cukup banyak setiap minggunya untuk jumlah video yang diunggah ke TikTok. Pertama-tama video dan naskah dikirim langsung oleh wartawan di lapangan kepada tim video TribunJabar.id melalui whatsapp, kemudian tim video akan mengerjakan editing dan setelahnya langsung diunggah di TikTok.

Pratinjau yang dilakukan oleh pimpinan redaksi di kedua media sebelumnya seharusnya dibutuhkan juga di TribunJabar.id. Karena hal ini bisa saja menimbulkan terjadinya kesalahan yang tidak terdeteksi, sebab tanpa melalui penyaringan biasanya dapat terlihat kekurangannya.

Tetapi hal ini dipatahkan oleh Mas Dicki selaku koordinator video dan admin TikTok TribunJabar.id yang memiliki tolok ukur dan mampu mendeteksi kekurangan dalam video yang diunggah berdasarkan pengalamannya di dunia jurnalistik.

Unsur-unsur jurnalistik yang diutamakan dalam pemberitaan di TikTok dari ketiga media khususnya $5 \mathrm{~W}+1 \mathrm{H}$ pun berbeda-beda. Dari hasil penelitian ditemukan CNBC Indonesia tidak begitu menerapkan hal tersebut dalam pemberitaanya di TikTok, menurutnya saat ini digital tidak sekaku itu. Meskipun beberapa video yang diunggah oleh CNBC Indonesia merupakan sebuah berita ekonomi yang dikemas dengan formal.

Berbeda dengan Urbanasia.com dan TribunJabar.id yang menyadari memang sudah menjadi suatu keharusan, berpegang kepada unsur-unsur jurnalistik. Meskipun tidak dapat dipungkiri terkadang ada saja human error yang tanpa disadari sehingga pemenuhan unsur jurnalistik tersebut terlewati.

Sedangkan dalam proses perkembangan zaman saat ini, meskipun sosial media tampak lebih santai untuk menyampaikan informasi, seharusnya hal utama seperti $5 \mathrm{~W}+1 \mathrm{H}$ ini tidak bisa ditinggalkan begitu saja terlebih oleh media massa.

Media massa sendiri memiliki empat fungsi dan peran di masyarakat yaitu dalam bidang informasi, pendidikan, hiburan dan juga persuasi.

Temuan penelitian yang dikemukakan oleh CNBC Indonesia tidak sejalan dengan salah satu fungsi dan peran media massa yaitu dalam bidang informasi. Inti dari fungsi informasi media yaitu merupakan konten media yang disebut berita.

Ketidak lengkapan unsur $5 \mathrm{~W}+1 \mathrm{H}$ dalam proses produksi sebuah video pemberitaan menjadikan fungsi CNBC Indonesia di TikTok sebagai media massa yang tidak memenuhi hal tersebut.

Kemudian dalam unsur teks di dalam pemberitaan baik caption, maupun yang diucapkan oleh host di setiap unggahan ketiga media di TikTok ini. CNBC Indonesia dan Urbanasia.com dalam hal ini memilih menggunakan bahasa sehari-hari yang lebih mudah untuk di mengerti dan tidak begitu formal. Menurut Aeni dalam (Octorina, 2018:732) terkait tulisan ataupun informasi di media massa dapat membantu mencerdaskan dan memberikan pemahaman yang akurat pada pembaca jika bahasa di media massa dapat dikemas dengan baik, variatif, tajam, mendalam dan juga lugas.

Dari penjelasan tersebut maka unsur teks di dalam pemberitaan media CNBC Indonesia dan Urbanasia.com dapat memberikan pemahaman yang tepat pada viewers nya jika dalam penggunaan bahasa sehari-hari dikemas dengan sangat baik.

Tulisan jurnalistik berbahan baku fakta sehingga untuk teks di dalam berita seorang jurnalis tidak perlu menggunakan bahasa yang muluk-muluk atau mendayu-dayu seperti pada karya sastra. (Musman\&Mulyadi, 2017:211). Berbeda dengan TribunJabar.id yang menyesuaikan dengan teks di website. Karena masih memiliki batasannya dan menunjukkan bahwa TribunJabar.id merupakan sebuah media massa formal.

Bentuk proses produksi video pemberitaan dari ketiga media ini memiliki banyak unsur yang disesuaikan dengan unsur jurnalistik dan citra perusahaan dalam merepresentasikan video pembertiaan. CNBC Indonesia memiliki standar yang khusus untuk video pemberitaannya, seluruh hal yang akan di unggah di TikTok tidak boleh terlihat kurang atau seadanya, suasana di dalam video pemberitaan harus mencerminkan CNBC Indonesia sebagai media massa yang formal.

Urbanasia.com dan TribunJabar.id tidak memiliki standar khusus dalam proses produksi 
video pemberitaan untuk mencerminkan branding dari media mereka, Urbanasia.com hanya cukup dengan berpatokan kepada pemberitaan di website dan mengubahnya menjadi sebuah berita di TikTok dengan caranya sendiri sebagai media massa anak muda.

Begitupun dengan TribunJabar.id yang sama-sama menggambarkan berita sesuai dengan apa yang terjadi dilapangan karena bahan yang diunggah pun berasal langsung dari lapangan.

Perbedaan dan persamaan dalam proses produksi video pemberitaan ketiga media di TikTok ini memberikan pandangan bahwa dalam menghasilkan sebuah karya jurnalistik, masih ada yang menganggap suatu unsur jurnalistik adalah hal utama namun ada juga yang menanggap itu bukan sebuah patokan dalam pembuatan karya jurnalistik di sosial media.

\section{Penerapan Etika dan Kaidah Jurnalistik oleh CNBC Indonesia, Urbanasia.com dan TribunJabar.id dalam Jurnalisme TikTok}

Penerapan etika dan kaidah jurnalistik dalam sebuah media tak hanya untuk memelihara dan menjaga standar dari kualitas yang dikerjakan oleh para jurnalis, namun untuk melindungi dan juga menghindarkan masyarakat dari kemungkinan yang berdampak merugikan dari tindakan ataupun perilaku janggal dari jurnalis yang bersangkutan. Menurut Marcelino (2016) dalam (Gawi, Aminulloh \& Yasak, 2017:21) etika jurnalistik harus memiliki standar peraturan perilaku dan moral, yang memandang patut pekerjaan yang dilaksanakan oleh seorang jurnalis. Etika jurnalistik dalam penelitian ini yaitu merupakan nilai atau norma yang dijadikan pedoman oleh media dalam menjalankan kegiatan jurnalistik yang merambah di dunia TikTok.

William L. Rivers dan Cleve Mathews (1994) memaparkan dalam (Musman \& Mulyadi, 2017:84) bahwa etika dalam media massa sangat dibutuhkan karena wartawan harus bebas dari kewajiban melayani kepentingan apapun, terkecuali hak public dalam mengetahui kebenaran. Maka dari itu dijelaskan pula oleh Musman dan Mulyadi (2017,84-85) terkait etika dalam bermedia yaitu:

1. Pemberian, kemurahan hati, maupun hak istimewa. Barang berharga tidak boleh diterima.

2. Pekerjaan sambilan, keterlibatan politik. Wartawan dan atasan harus memiliki kehidupan pribadi yang menghindari mereka dari konflik kepentingan.

3. Tidak menyiarkan berita tanpa adanya pengakuan langsung dari sumber.

4. Mencari berita yang melayani kepentingan publik.

5. Mengakui etikanya untuk melindungi kerahasiaan sumber informasi.

6. Plagiarisme tindakan yang tidak bisa diterima.

Dalam temuan penelitian yang ditemukan peneliti CNBC Indonesia memiliki etika yang perlu dipatuhi oleh para reporter nya, CNBC Indonesia memiliki standar etika jurnalistik yang sama seperti penjelasannya dalam proses produksi video pemberitaannya. Reporter CNBC Indonesia tidak diperbolehkan untuk mengunggah berita dengan visual yang tidak masuk ke dalam standar CNBC Indonesia sebagai media ekonomi formal. Misalnya, video yang diunggah harus berlatar kantor dan tidak direkam dari rumah.

Untuk pemilihan orang yang tampil dalam video pemberitaannya di TikTokpun mereka memilih langsung anchor yang terbiasa muncul di televisi karena berdasarkan pengalaman para anchor ini jauh lebih kompeten.

Hal ini sejalan dengan penjelasan diatas, bahwa yang dilakukan oleh CNBC Indonesia menghindari untuk terjadinya dampak yang dapat merugikan, baik untuk masyarakat maupun perusahaan medianya itu sendiri.

Urbanasia.com menerapkan etika jurnalistik dengan cara yang berbeda dengan memenuhi unsur-unsur jurnalistik yang diterapkan dalam video pemberitaannya di TikTok. Urbanasia.com memaksimalkan informasi dari berita yang diunggah di website untuk tersampaikan secara keseluruhan juga mengkombinasikannya dengan fitur yang disediakan oleh TikTok, dalam proses pembuatan naskahpun mereka memperhatikan etika jurnalistik di dalamnya.

Untuk TribunJabar.id, Dicki memiliki hal yang lebih ketat dari kedua media sebelumya. Sebisa mungkin berita yang diunggah oleh TribunJabar.id di TikTok tidak mengandung unsur extreme. TribunJabar.id akan lebih selektif dalam pemilihan berita meskipun berita tersebut 
berpotensi untuk viral yang dapat menguntungkan perusahaan.

Hal ini menunjukkan independensi yang memang tertanam di TribunJabar.id sebagai media massa. Independensi sendiri menurut Dewan Pers adalah peristiwa ataupun fakta yang sesuai dengan suara hati nurani, tanpa adanya campur tangan dari pihak lain. TribunJabar.id menunjukkan bahwa hal-hal extreme tidak akan mereka pilih dalam pemberitaannya di TikTok karena dianggap terlalu eksplisit dan cukup mengganggu, ini merupakan sikap yang diambil dalam menerapkan etika jurnalistik.

Kemudian merujuk kepada kaidah jurnalistik yang dimaksudkan dalam penelitian ini yaitu sebuah aturan pasti yang dijadikan patokan oleh ketiga media ini. CNBC Indonesia menyatakan bahwa kaidah jurnalistik yang diterapkan pada video pemberitaan di TikTok merujuk kepada pemberitaan di website yang pastinya sudah lolos melalui penyaringan oleh editor.

Membuat video pemberitaan di TikTok menjadi hal yang cukup serius di garap oleh Urbanasia.com dalam melebarkan sayapnya di media sosial. Urbanasia.com yang memastikan bahwa seluruh informasi dari website tersampaiakan sehingga kaidah jurnalistikpun sudah pasti disesuaikan. Misalnya dengan selalu menyebut asal sumber informasi yang mereka dapat dan sebisa mungkin di TikTok keseluruhan isi berita di website dapat tersampaikan.

Sedangkan TribunJabar.id yang mengedepankan etika jurnalistik dalam pemberitaannya, memiliki jawaban berbeda terkait kaidah jurnalistik yang digantungkan kapada kontennya. Ketika konten video pemberitaan tidak begitu rumit, TribunJabar.id lebih flexible saja. Kaidah yang terpenuhi cukup dari gambar yang disajikan.

Sedangkan untuk teks pemberitaan dalam video dan judulnya juga mengikuti. Hal ini menimbulkan ketidak berimbangan dari etika dan kaidah jurnalistik yang diterapkan di akun TikTok TribunJabar.id. Berikut disajikan dalam tabel perbandingan penerapan etika dan kaidah jurnalistik oleh ketiga media dalam penelitian ini.

Tabel 3.2 Perbandingan Etika dan Kaidah Jurnalistik di Ketiga Media

\begin{tabular}{|c|c|c|}
\hline Media & Etika Jurnalistik & Kaidah Jurnalistik \\
\hline CNBC Indonesia & $\begin{array}{l}\text { - Berita yang diunggah } \\
\text { harus memiliki visual } \\
\text { sesuai standar } \\
\text { - Pemilihan anchor untuk } \\
\text { tampil dalam video }\end{array}$ & $\begin{array}{l}\text { Selama berita sudah } \\
\text { ada di website, kaidah } \\
\text { jurnalistik berarti } \\
\text { sudah diterapkan }\end{array}$ \\
\hline Urbanasia.com & $\begin{array}{l}\text { - Memenuhi unsur-unsur } \\
\text { jurnalistik. } \\
\text { - Diterapkan etika } \\
\text { jurnalistik dari } \\
\text { pembuatan naskah } \\
\text { - Memaksimalkan fitur } \\
\text { yang disediakan } \\
\text { TikTok }\end{array}$ & $\begin{array}{l}\text { - Selalu menyebutkan } \\
\text { asal sumber } \\
\text { informasi. } \\
\text { - Sebisa mungkin } \\
\text { keseluruhan isi berita } \\
\text { dari website dapat } \\
\text { tersampaikan } \\
\text { sehingga informasi } \\
\text { disuguhkan secara } \\
\text { keseluruhan tidak di } \\
\text { potong. }\end{array}$ \\
\hline TribunJabar.id & $\begin{array}{l}\text { - Berita yang diunggah } \\
\text { tidak mengandung } \\
\text { unsur extreme } \\
\text { - Selektif dalam } \\
\text { pemilihan berita }\end{array}$ & $\begin{array}{l}\text { - Tergantung dengan } \\
\text { konten. } \\
\text { - Cukup dari gambar } \\
\text { yang disajikan } \\
\text { - Teks pemberitaan dan } \\
\text { judul mengikuti }\end{array}$ \\
\hline
\end{tabular}

Sumber: Olahan Data Peneliti

\section{Kesimpulan}

Melihat penjelasan diatas dapat disimpulkan bahwa pemanfaatan platform TikTok oleh ketiga media sebagai platform pemberitaan memiliki cara yang berbeda-beda dengan latar belakang kehadiran yang berbeda pula. Seperti CNBC Indonesia sebagai media ekonomi yang memiliki gaya pemberitaan formal namun turut hadir di TikTok dan berusaha untuk menyesuaikan format 
yang ada.

Urbanasia.com memiliki model pemberitaan yang berbeda dan nyentrik, dengan dibacakan langsung oleh host, pemberitaan yang diunggah seolah-olah seperti para influencer TikTok yang sedang berinteraksi dengan followersnya membuat followers media ini terus melambung.

Sedangkan TribunJabar.id mengungaah pemberitaan dengan gaya video langsung dari Tempat Kejadian Perkara, sehingga sulit untuk dipungkiri bahwa berita yang disebarkan memang nyata dari apa yang terjadi dilapangan.

Namun hal tersebut dapat diketahui bahwa secara garis besar dalam memanfaaatkan platform TikTok tujuan ketiga media ini memiliki kesamaan yaitu untuk branding, dan juga meraup pembaca medianya lebih banyak lagi dari segmen biasanya sehingga informasi yang disampaikan dapat diketahui oleh banyak kalangan, khususnya sebagai target ketiga media ini yaitu kalangan anak muda yang menggandrungi aplikasi TikTok ini.

Kemudian dalam proses produksi video pemberitaan pun, cara yang dilakukan berbedabeda pula ada yang memiliki proses lebih banyak dan juga lebih komplex dan ada juga yang proses nya cukup singkat. Ini memberikan pengaruh terhadap banyaknya video yang ketiga media ini unggah disetiap minggunya. Seperti CNBC Indonesia memiliki proses yang cukup panjang sehingga, target setiap minggu hanya satu sampai dua video untuk diunggah di TikTok.

Sedangkan TribunJabar.id karena memiliki proses yang sangat singkat, menjadikan targetnya setiap minggu cukup banyak video yang harus diunggahnya. Berbeda dengan keduanya Urbanasia.com meskipun memiliki proses yang panjang namun setiap harinya selalu ada berita yang mereka unggah di TikTok. Hal ini menunjukkan bahwa Urbanasia.com menjadi salah satu media baru yang masih segar dan ter up to date.

Terpenting ketiga media masing-masing ingin menunjukkan gaya nya sendiri dalam merepresentasikan video pemberitaannya di TikTok dalam hal ini unsur-unsur jurnalisik khususnya unsur utama $5 \mathrm{~W}+1 \mathrm{H}$ tidak begitu di penuhi oleh salah satu media dalam penelitian ini.

Meskipun hal tersebut merupakan sesuatu yang penting dalam kegiatan berjunalistik tetapi dengan kehadirannya memilih menggunakan cara lain dalam menerapkan unsur-unsur tersebut dapat dianggap hal ini tidak begitu menjadi masalah besar.

Beranggapan bahwa dunia digital saat ini tidak sekaku dahulu kala, meskipun seharusnya unsur utama terlebih dalam mengedepankan fungsi media untuk memenuhi kebutuhan informasi seharusnya hal daasar yang menjadi kekuatan sebuah informasi menjadi topic utama yang dibahas dalam sebuah pemberitaan.

Lalu, teori mengenai etika dan kaidah jurnalistik yang sudah ada terkadang berbeda dengan yang sebenarnya terjadi di lapangan. Proses representasi kedua hal tersebut terlihat cukup sulit dilakukan saat ini. Satu sisi ketika mengedepankan unsur formal media massa nya, adanya ketakutan untuk ditinggalkan oleh para viewers.

Sisi lain, ada yang menggunakan caranya sendiri dalam menjalankan fungsi media yang dikenal sebagai agent of change. Namun dengan perkembangan yang kian pesat beragam masalah sudah memiliki solusi dan alternatif nya sendiri. Beragam cara dicoba demi mendapatkan formula yang tepat menyesuaikan dengan tujuan dari media-media ini sendiri.

Beradaptasi dengan media sosial sendiri harus terus berkembang, sehingga untuk mencapai tujuan utama sebagai media massa akan terwujud. Meskipun beberapa cara yang dilakukan terkadang tidak sesuai dengan teori yang berlaku. Maka dari itu dapat dinilai bahwa penerapan etika dan kaidah jurnalistik yang diterapkan dalam pemberitaan ketiga media ini di TikTok bersifat flexible.

Penerapan etika serta kaidah jurnalistik sudah bisa di modifikasi dengan cara-cara yang lebih modern serta untuk mendapatkan target market kalangan kaum anak muda bisa terbawa kedalam arus yang diciptakan oleh media itu sendiri. Jika masih bersikukuh dengan cara-cara lama untuk menerapkan hal tersebut, memungkinkan pasar anak muda yang ditargetkan sulit untuk dicapai. 
126 | Jilan Dwina SP, et al.

\section{Acknowledge}

Terimakasih kepada dosen pembimbing saya Ibu Ratri Rizki K, S. Sos., M. I. Kom atas bimbingannya sehingga penelitian ini bisa selesai sebagaimana yang diharapkan.

\section{Daftar Pustaka}

[1] Chapple, Craig. 2020. " TikTok Crosses 2 Billion Downloads After Best Quarter For Any App Ever". https://sensortower.com/blog/tiktok-downloads-2-billion. Tanggal akses 4 April 2021.

[2] Coteau D., \& W. Hoynes. 1997. Media and Society. Amerika: SAGE

[3] Gawi, Gebriel. Aminulloh, A. Yasak, M.E. 2017. Penerapan Kode Etik Dalam Surat Kabar Harian Surya Malang. Malang: Universitas Tribhuwana Tunggadewi. Vol.6 No.1. ISSN 2442-6962.

[4] McQuail, Denis. 2011. Teori Komunikasi Massa McQuail. Jakarta: Salemba Humanika.

[5] Musman, Asti. Mulyadi, Nadi. 2017. Jurnalisme Dasar Paduan Praktis Para Jurnalis. Bantul: Komunika

[6] Nasrullah, Rulli. 2014. Teori dan Riset Media Siber (Cybermedia) Edisi pertama. Jakarta: Prenadamedia Group

[7] Octorina, M.I. Karwinati,D. Aeni,S.E. 2018. Pengaruh Bahasa di Media Sosial Bagi Kalangan Remaja. Jurnal Pendidikan Bahasa dan Sastra Indonesia. IKIP Siliwangi. Vol 1, No 5. Issn 2614$624 X$.

[8] Ridhoi, Ahsan Muhammad. "Resep TikTok Merebut Pasar Youtube dan Instagram". https://katadata.co.id/muhammadridhoi/analisisdata/5fd775b943af0/resep-tiktok-merebut-pasaryoutube-dan-instagram. Tanggal akses 4 April 2021.

[9] Santana. K. Septiawan. 2005. Jurnalisme Kontemporer.Jakarta : Yayasan Obor Indonesia. Hal. 137 